\title{
Vércukorcsökkentő gyógyszerek biztonságossága szívelégtelenségben
}

\author{
Frigy Attila dr. ${ }^{1}$. Germán-Salló Márta dr. ${ }^{2}$ \\ Máthé Lehel $\mathrm{dr}^{3}{ }^{3}$ - Szabó Mónika dr. ${ }^{2}$
}

\author{
Marosvásárhelyi Orvosi és Gyógyszerészeti Egyetem (UMF Tg. Mureș), ${ }^{1}$ IV. Belgyógyászati Tanszék, \\ ${ }^{2}$ III. Belgyógyászati Tanszék, ${ }^{3}$ VII. Belgyógyászati Tanszék, Marosvásárhely, Románia
}

\begin{abstract}
A diabetes és szívelégtelenség társulása igen gyakori, ugyanakkor a két kórkép patofiziológiája és kórlefolyása is számos ponton találkozik. Napjainkban a rendelkezésre álló antidiabetikus gyógyszerek spektruma rendkívül széles, a klasszikus szerektől (inzulin, biguanidok, szulfanilureák) a legmodernebbekig (gliptinek, gliflozinok) terjed. Ezeknek a gyógyszereknek a cardiovascularis hatásai sokrétúek, ismeretük fontos a mindennapi gyakorlatban, ugyanis előnyben részesül a szívelégtelenség szempontjából biztonságos szerek alkalmazása. Munkánk áttekintést nyújt az egyes gyógyszercsoportokról - a hatásmechanizmus, valamint a főbb képviselők bemutatása után ismertetjük a cardiovascularis rendszerre és ezen belül a szívelégtelenségre gyakorolt hatásokat, megemlítve a fontosabb klinikai vizsgálatok eredményeit is. Az adatok egyértelmúen alátámasztják a metformin és a gliflozinok kedvező és a thiazolidindionok káros hatását szívelégtelenségben. A többi gyógyszercsoport alkalmazása megengedett szívelégtelenség esetén, de fontos a dekompenzáció jeleinek folyamatos monitorozása. Orv. Hetil., 2017, 158(5), 163-171.
\end{abstract}

Kulcsszavak: diabetes mellitus, vércukorcsökkentő gyógyszerek, szívelégtelenség

\section{The safety of anti-diabetic drugs in heart failure}

The association of diabetes and heart failure is very common, furthermore, the pathophysiology and clinical course of the two entities have many crossing-points. Today, the spectrum of available anti-diabetic drugs is extremely wide, ranging from the classical (insulin, biguanides, sulphonylureas) to the most recent agents (gliptins, gliflozins). The cardiovascular effects of these drugs are multiple, their knowledge is important in the everyday practice, as the use of safe drugs regarding of heart failure is preferred. Our work provides an overview of each class of drugs after the presentation of the mechanism of action and the main representatives, the effects on the cardiovascular system, including those on heart failure will be described, mentioning the results of the most important clinical trials. The available data confirm the beneficial effects of metformin and gliflozins and the harmful effect of thiazolidinediones in heart failure. The other classes of drugs are permitted in heart failure, but it is important to continuously monitor the signs of decompensation.

Keywords: diabetes mellitus, anti-diabetic agents, heart failure

Frigy, A., Germán-Salló, M., Máthé, L., Szabó, M. [The safety of anti-diabetic drugs in heart failure]. Orv. Hetil., 2017. $158(5), 163-171$.

(Beérkezett: 2016. október 29.; elfogadva: 2016. november 30.)

\section{Rövidítések}

ADVANCE $=$ Action in Diabetes and Vascular Disease: Preterax and Diamicron MR Controlled Evaluation; CANVAS = Canagliflozin Cardiovascular Assessment Study; DECLARETIMI 58 = Dapagliflozin Effect on Cardiovascular Events; DYDA = Left Ventricular Dysfunction in Type 2 Diabetes Mellitus; ELIXA = Evaluation of Lixisenatide in Acute Coronary Syndrome; EMPA-REG OUTCOME = Empagliflozin Cardio- vascular Outcome Event Trial in Type 2 Diabetes Mellitus Patients; EXAMINE = Examination of Cardiovascular Outcomes with Alogliptin versus Standard of Care; FDA = Food and Drug Administration; GLP-1 = glucagon like peptid-1; LEADER = Liraglutide Effect and Action in Diabetes: Evaluation of Cardiovascular Outcome Results; NAVIGATOR = Nateglinide And Valsartan in Impaired Glucose Tolerance Outcomes Research; ORIGIN = Outcome Reduction with an Initial 
GlargineIntervention;PPAR-gamma = peroxiszómaproliferátoraktivált-receptor-gamma; PROACTIVE = Prospective Pioglitazone Clinical Trial in Macrovascular Events; RECORD = Rosiglitazone Evaluated for Cardiovascular Outcomes; SAVOR-TIMI 53 = Saxagliptin Assessment of Vascular Outcomes Recorded in Patients with Diabetes Mellitus; SGLT = glükózkotranszporter; SGLT-2 = nátriumhoz kapcsolt sodium-glucose-cotransporter; STOP-NIDDM = The Study to Prevent Non-Insulin-Dependent Diabetes Mellitus; SUSTAIN-6 = Semaglutide in Subjects with Type 2 Diabetes; SzE = szívelégtelenség; TECOS = Trial to Evaluate Cardiovascular Outcomes after Treatment with Sitagliptin; UGDP = University Group Diabetes Program; UKPDS = UK Prospective Diabetes Study

A diabetes napjaink egyik legjelentősebb népbetegsége, előfordulása folyamatosan nő, Európában megközelíti a 9\%-ot a 20 év feletti korosztályban [1]. A 2-es típusú diabetes az atheroscleroticus eredetü cardiovascularis megbetegedések, valamint a szívelégtelenség (SzE) kialakulásának egyik fó rizikófaktora. Diabetes esetén az SzE megjelenésének valószínüsége férfiakban 2,4-szeres, míg nőkben ötszörös a népesség egészéhez képest. $\mathrm{Cu}$ korbetegség és SzE együttes előfordulása igen gyakori: SzE-ben a diabetesesek aránya $24-40 \%$, míg cukorbetegség esetén $\mathrm{SzE}$ a betegek $22 \%$-ában van jelen (65 éves kor felett), négyszer gyakrabban, mint az átlagnépességben. A két kórkép társulása kölcsönösen fokozza a mortalitást és a kórházi beutalások számát [2-5].

A diabetes az SzE megjelenését és progresszióját elsősorban az akcelerált (kiterjedés, súlyosság) coronariabetegség révén idézi elő, ugyanakkor létezik egy specifikus, primer myocardialis érintettség is (diabeteses cardiomyopathia), amelynek kialakulásában a hyperinsulinaemia, illetve a hyperglykaemia által beindított komplex kórfolyamatok játszanak szerepet. Ezekhez adódik hozzá a diabeteses autonóm cardialis neuropathia, amely az aritmogenezis egyik fontos faktora. Másfelől az SzE is elősegíti a diabetes megjelenését és progresszióját, az inzulinrezisztencia fokozása által. A patomechanizmus meglehetősen összetett és magába foglalja a szimpatikus idegrendszer túlmúködését, a fokozott lipolízist, a reninangiotenzin-aldoszteron rendszer aktiválódását, a citokinek termelódését, valamint a vázizmok viszonylagos inaktivitását. Megállapítható tehát, hogy az SzE és diabetes összefonódása ördögi kört alkot, nagyban hozzájárulva az érintett betegek életminőségének és prognózisának romlásához [5-7].

A fentiekból kiindulva nyilvánvaló, hogy az antidiabetikus szerek cardiovascularis, illetve SzE-re gyakorolt hatásainak ismerete a klinikai gyakorlat szempontjából elengedhetetlen. A biztonságos gyógyszerek alkalmazása ajánlott, vagyis azoké, amelyek hozzájárulnak az SzE kialakulásának megelőzéséhez, illetve nem okozzák az esetleg már fennálló dekompenzáció súlyosbodását $[8$, 9]. Ez az elv annál is inkább fontos, mert az intenzívebb anyagcserekontroll önmagában nem vezet az SzE-hez köthető események (mortalitás, kórházi beutalások) szignifikáns csökkenéséhez a két kórkép együttes fennállása esetén $[10,11]$. Az antidiabetikus szereknek az SzE szempontjából releváns, lehetséges támadáspontjait az 1. táblázatban tüntettük fel.

A továbbiakban áttekintést nyújtunk a diabetes kezelésében alkalmazott fontosabb gyógyszercsoportokról a hatásmechanizmus, valamint a főbb képviselők bemutatása után ismertetjük a cardiovascularis rendszerre, ezen belül az SzE-re gyakorolt hatásokat, utalva a fontosabb klinikai vizsgálatok eredményeire is.

\section{Inzulin}

Az inzulin hatásai meglehetősen sokrétúek, az általános és myocardialis cukoranyagcsere befolyásolásán túl (fokozott glükózfelvétel, glikogénképzés és glikolízis) számos elemet foglalnak magukba: pozitív inotrop hatás, mitogén hatás, nitrogén-oxid-szintézis (vasodilatatio), endotelinszekréció (vasoconstrictio), a szimpatikus idegrendszer stimulációja, dózisfüggő antinatriureticus hatás (következményes folyadékretencióval). Ez utóbbi inzulinrezisztencia esetén is megmarad és bár nem kifejezetten, de hozzájárulhat egy már fennálló SzE súlyosbodásához [12].

Bár léteznek adatok arra nézve, hogy 2-es típusú diabetesben az inzulinterápia bevezetése, társítása az orális szerekhez fokozhatja az SzE incidenciáját és a cardiovascularis eseményeket, a kérdés nincs eldöntve. Ismert tény ugyanis, hogy az inzulinra szoruló betegek általában idősebbek és több szövődménnyel (micro- és macrovascularis), illetve komorbiditással (hypertonia, renalis érintettség) rendelkeznek, ami magyarázhatja az inzulinkezelés látszólag kedvezôtlen hatását [13]. A UKPDS (UK Prospective Diabetes Study) vizsgálat nem talált különbséget az SzE előfordulásában az inzulinnal kezelt betegeknél a szulfanilureát kapókhoz képest [14]. A glargin inzulin vs. placebóval végzett ORIGIN (Outcome Reduction with an Initial Glargine Intervention) vizsgálatban az inzulinnal kezelt betegeknél a cardiovascularis események, köztük az SzE miatti kórházi beutalások előfordulása nem nőtt a hatéves követési idő végére [15]. Ezeknek az adatoknak mond ellent a Smooke és mtsai által végzett megfi-

1. táblázat Antidiabetikus szerek szívelégtelenség szempontjából releváns, lehetséges támadáspontjai

\begin{tabular}{ll}
\hline Közvetlen támadáspontok & Közvetett támadáspontok \\
\hline Myocardialis energiaháztartás & Renin-angiotenzin-aldoszteron \\
Coronaria-mikrocirkuláció & rendszer \\
Kontraktilitás & Natriureticus peptidek \\
Relaxáció & Szimpatikus idegrendszer \\
Aritmogenezis & Endotheliumfunkció \\
& Szisztémás gyulladás \\
& Folyadékmérleg \\
& Testsúly \\
& Vérnyomás \\
& Lipidszintek \\
& Vércukorszint \\
\hline
\end{tabular}


gyeléses vizsgálat, amelyben az inzulinnal kezelt szívelégtelen betegek egyéves túlélési aránya jóval kisebbnek mutatkozott, mint az inzulint nem kapóké $(62,1 \%$ vs. $85,8 \%$ ), úgy, hogy az inzulinkezelés független rizikófaktornak bizonyult (4,3-szoros kockázat) [16].

Összefoglalásképpen elmondható, hogy az inzulinkezelésnek, ha van is az SzE-t negatívan befolyásoló hatása, az valószínúleg kisfokú, és leginkább az inzulint igényló betegek magasabb rizikójával magyarázhatók a látszólag kedvezőtlen hatások.

\section{Biguanidok (metformin)}

A biguanidok a 2-es típusú cukorbetegség kezelésének első vonalbeli gyógyszerei, mára gyakorlatilag egyedülivé vált képviselőjük a metformin [10]. A biguanidok növelik az inzulinérzékenységet azáltal, hogy csökkentik a máj glükóztermelését (a glükoneogenezist) és növelik a perifériás glükózfelhasználást. A szívizomban fokozzák a glükózfelvételt és a glikolízist, illetve csökkentik a mitokondriumok szabadzsírsav-felvételét, ezáltal optimalizálják, gazdaságosabbá teszik a myocardialis energiatermelést [17]. Állatkísérletekben a metformin kardioprotektívnek bizonyult ischaemia és reperfúzió esetén [18].

A metformin számos előnnyel rendelkezik a diabetes kezelésében: nem okoz hypoglykaemiát, csökkenti a testsúlyt, a vérnyomást és a vérzsírszinteket, fibrinolitikus hatású és kedvezően befolyásolja az endotheldiszfunkciót. E komplex hatások eredőjeként csökkenti a diabeteshez köthető klinikai eseményeket (cardiovascularis és összmortalitás, myocardialis infarctus, agyi történések) [19, 20].

Számos vizsgálat és metaanalízis bizonyítja a metformin kedvező hatásait az SzE-re vonatkozóan [21, 22]. A gyógyszer csökkenti az SzE megjelenésének valószínüségét és mortalitását a szulfanilureákhoz és a glitazonokhoz képest, és pozitív hatásai előrehaladott $\mathrm{SzE}$, súlyosan megromlott balkamra-funkció esetén is megmutatkoznak [23-25]. Kórházi beutalás esetén a metforminnal kezelt szívelégtelen betegeknél alacsonyabb volt az egyéves mortalitás, illetve az újbóli beutalások száma a szulfanilureát és inzulint kapókhoz képest [23].

Fontos megjegyezni, hogy egyik vizsgálat vagy metaanalízis sem támasztotta alá a tejsavacidózis fokozott előfordulását SzE-ben metformin adagolásakor. Ugyanakkor súlyos hypoxaemia, illetve instabil hemodinamikai állapot esetén az óvatosság továbbra is ajánlott [8].

Összefoglalásképpen elmondható, hogy biztonságossága és számtalan, vizsgálatokkal bizonyított kedvező cardiovascularis hatása miatt $\mathrm{SzE}$ és diabetes társulása esetén a metformin elsőként ajánlott szer.

\section{Glitazonok (thiazolidindionok)}

A glitazonok vagy thiazolidindionok hatásukat úgy fejtik ki, hogy magas affinitással kötődnek egy intranukleárisan elhelyezkedő receptorhoz, a PPAR-gammához (peroxiszómaproliferátoraktivált-receptor-gamma) [26]. Egyedüli engedélyezett képviselőjük Európában a pioglitazon. A másik szer, a rosiglitazon forgalmazását felfüggesztették 2010-ben a myocardialis infarctus előfordulásának szignifikáns növekedése miatt (kockázati arány 1,28) [27].

A PPAR-gamma egyike azon receptoroknak, amelyek a szénhidrát- és zsíranyagcserében szerepet játszó proteinek szintjét (tulajdonképpen a felelős gének transzkripcióját) szabályozzák, és 10-30-szor nagyobb koncentrációban van jelen a zsírszövetben, mint a májban vagy az izmokban. A glitazonok elsősorban a zsírszövetben, de az izmokban és a májban is javítják az inzulinérzékenységet (glükózfelvételt), és bizonyos mértékben gátolják a májban a glükoneogenezist. A pioglitazon lipidprofilja kedvező, enyhén csökkenti az LDL- és növeli a HDLkoleszterin-szintet, emellett a PPAR-alfa-receptort is aktiválja, ezáltal csökkenti a trigliceridszintet. A gyógyszercsoportnak gyulladáscsökkentő és antitumorális hatása is van. Fontos, hogy a 2-es típusú diabetest gyakran kísérő hypertriglyceridaemia egyik gyógyszere, a CYP2C8-at gátló hatású gemfibrozil egyidejü szedése lassíthatja a pioglitazon eliminációját, illetve, hogy pioglitazon használatakor a májenzimek gondos monitorozása szükséges $[28,29]$.

Kedvezőtlen általános hatásokként említhetők a testsúlynövekedés (átlagban $2 \mathrm{~kg}$, de a zsigeri zsírszövet áthelyeződésével) és a folyadékretenció, amelyért a distalis tubulusban történő fokozott nátriumreabszorpció a felelős. Ez utóbbi mellékhatás miatt ellenjavalltak SzE-ben $[30,31]$. A folyadékretenciót a nem szteroid gyulladáscsökkentők (például indomethacin) egyidejü használata tovább fokozhatja.

A gyógyszercsoport kedvező vascularis hatásokkal rendelkezik - a carotis intima-media vastagság csökkenése, a coronariaplakkok regressziója [8], illetve a kemény klinikai végpontok (összmortalitás, nem fatális infarktus, stroke) szignifikáns csökkenése - a PROACTIVE (Prospective Pioglitazone Clinical Trial in Macrovascular Events) vizsgálatban [32]. A pioglitazon kedvező vascularis hatásait egy 16390 beteg adatait feldolgozó metaanalízis is megerősítette (kockázati arány 0,82) [33]. Medicare-gondozásban levő betegek adatainak retrospektív analízise során azt találták, hogy a pioglitazont szedő betegeknél szignifikánsan alacsonyabbnak mutatkozott az SzE, stroke és elhalálozás előfordulása, mint a rosiglitazont kapóknál [34].

A RECORD (Rosiglitazone Evaluated for Cardiovascular Outcomes) és a PROACTIVE vizsgálatok, valamint a metaanalízisek alapján úgy a rosiglitazon, mint a pioglitazon növelik az SzE előfordulását: a kockázati arány 2,1, illetve 1,4 a két szer esetén [32, 35-37].

Összefoglalásképpen elmondható, hogy bár a pioglitazon rendelkezik kedvező vascularis hatásokkal, a gyógyszer használata meglehetősen visszaszorult, SzEben pedig ellenjavallt. 


\section{Alfa-glükozidáz-gátlók}

Viszonylag kis hatékonyságú szerek, az alfa-glükozidáz enzimek reverzibilis inhibitorai, csökkentik a keményítő, a dextrin és a diszacharidok lebontását, lassítják a glükózfelszívódást, mérséklik a postprandialis vércukorszintemelkedést és a napszaki vércukorszint-ingadozást [28]. Forgalomban levő képviselőjük az akarbóz, amelynek lipidcsökkentő és kedvező cardiovascularis hatásai vannak, viszont gyakoriak a gastrointestinalis mellékhatásai (görcsök, flatulentia, hasmenés), ami behatárolja mindennapi alkalmazhatóságát [30,38].

A STOP-NIDDM (The Study to Prevent Non-Insulin-Dependent Diabetes Mellitus) vizsgálatban az akarbóz szignifikánsan csökkentette a cardiovascularis események (összevont végpont), elsősorban a myocardialis infarctus rizikóját (kockázati arány 0,47 ), beleértve az SzE megjelenését is, csökkent glükóztoleranciájú betegek esetén [39]. Ugyanakkor a gyógyszerre vonatkozó metaanalízisek következtetései ellentmondóak, ami a cardiovascularis biztonságosságot illeti $[40,41]$.

Összegzésképpen elmondható, hogy az akarbóz SzEben adható, biztosan nem ellenjavallt, de lehetséges pozitív hatásai mind ez idáig nem kerültek egyértelmú megerősítésre.

\section{Szulfanilureák}

A szulfanilureák a legrégebben használt antidiabetikus gyógyszerek közé tartoznak, és jelenleg a 2-es típusú cukorbetegség kezelési algoritmusában második vonalbeli szerként vagy ráépített terápiaként javasoltak. Inzulinszekretagógok, serkentik az inzulinelválasztást. E hatásukat a hasnyálmirigy béta-sejtjeinek felszínén levő szulfanilureareceptorokhoz (SURl) való kötődés útján fejtik ki, amely kötődés zárja az ATP-függő káliumcsatornákat, amit a sejtmembrán depolarizálódása, a feszültségfüggő kalciumcsatornák megnyílása, intracelluláris kalciumfelhalmozódás és végül az inzulinszekréció fokozódása követ $[10,28,30]$. Növelik úgy az étkezés utáni inzulinszekréciót, mint a bázisinzulin termelődését, ezért gyakrabban okoznak hypoglykaemiát, mint más vércukorcsökkentő szerek [42].

A szulfanilureacsaládon belül megkülönböztetjük az első generációs szereket (tolbutamid, tolazamid, chlorpropamid), valamint a hatékonyabb és biztonságosabb második generációs szereket - glibenclamid, gliclazid, glipizid, gliquidon, glimepirid. A gliclazid a benzamidocsoport hiánya miatt csak a hasnyálmirigy szulfanilureareceptoraihoz képes kötődni, míg a glimepirid funkcionálisan pancreasszelektív. A többi készítmény más szövetek, így a cardiovascularis rendszer receptoraihoz (SUR2) is kötődik. A gliclazid előnyös receptoriális hatása mellett nem receptoriális sajátosságként antioxidáns, szövetkultúrában antiapoptotikus és kedvező haemorrheologiai hatással is rendelkezik $[28,42]$.
Fontos mellékhatásuk a cardiovascularis rendszert is érintő, károsító, általában elhúzódó hypoglykaemia, amely leginkább a tartós hatású készítmények, illetve a glibenclamid adásakor jelentkezik. Hypoglykaemiát okozó hatásukat fokozza a szalicilátok és kumarinszármazékok társítása [42]. Ugyancsak előnytelen hatás szívelégtelen betegeknél az étvágy és a testsúly növekedése [9].

A nem pancreasszelektív szerek növelik a coronariák vascularis rezisztenciáját, illetve az ischaemiás prekondicionálás gátlásával csökkentik a szívizom hypoxiával szembeni ellenálló képességét $[8,9]$.

Első generációs szulfanilureákkal végzett korai tanulmányok, mint az UGDP (University Group Diabetes Program) eredményei azt mutatták, hogy ezek növelik a cardiovascularis események előfordulását és a mortalitást 2-es típusú diabeteses betegeknél. Később randomizált klinikai tanulmányok, amelyekben antidiabetikus szerként szulfanilureák is szerepeltek, mint a UKPDS (chlorpropamid, glibenclamid, glipizid) vagy az ADVANCE (Action in Diabetes and Vascular Disease: Preterax and Diamicron MR Controlled Evaluation, gliclazid) igazolták, hogy a jobb glykaemiás kontroll nem befolyásolja a macrovascularis események előfordulását, az össz- és cardiovascularis (12\%-os, nem szignifikáns csökkenés) mortalitást és az SzE miatti hospitalizációt [9, 13, 38, 43]. Ugyanakkor a UKPDS tanulmány 10 éves utánkövetése kimutatta, hogy a macrovascularis események 16\%-kal, az akut myocardialis infarctus 15\%-kal, az összmortalitás 13\%-kal, az SzE előfordulása pedig 16\%-kal csökkent a szulfonilureával vagy inzulinnal kezelt, intenzív kontrollú betegcsoportban [44]. Más tanulmányok úgy találták, hogy a metforminnal összehasonlítva a második generációs szulfanilureák nem befolyásolják a cardiovascularis összmortalitást, de csökkentik a nem fatális cardiovascularis események elófordulását, a gyakrabban és súlyosabb formában jelentkező hypoglykaemia árán. Az ADVANCE tanulmányban a súlyos hypoglykaemia több mint háromszorosára növelte a macrovascularis események előfordulását és a mortalitást $[45,46]$. Egy 2016-ban közölt metaanalízis 47 klinikai vizsgálat adatainak feldolgozása alapján arra a következtetésre jutott, hogy a második generációs szulfanilureák biztonságosak úgy monoterápiában, mint metforminhoz társítva, nem növelik sem az össz-, sem a cardiovascularis mortalitást, illetve a myocardialis infarctus vagy a stroke kockázatát [47]. Megjegyezzük, hogy a korai vizsgálatok negatív eredményei valószínúleg az első generációs szulfanilureakészítmények kiterjedt használata miatt jelentkeztek. Cardiovascularis betegség fennállása esetén vagy magas kockázatú betegeknél a szulfanilureák fokozták a cardiovascularis mortalitást, az összmortalitást és a nem fatális myocardialis infarctus előfordulását a metforminhoz képest [9, 48]. Összehasonlítva a csoporton belüli szereket, a glibenclamidhoz képest a gliclazid és a glimepirid használata kisebb össz- és cardiovascularis mortalitással társul [49]. 
A szulfanilureák SzE-re gyakorolt hatását illetően egyetlen randomizált klinikai vizsgálat létezik, amely öszszehasonlította a glyburidot a pioglitazonnal és azt találta, hogy a szulfanilvegyületet kapó betegeknél kevesebb volt az SzE miatti hospitalizáció [50]. A nagy vizsgálatok alcsoport-analízisei, a megfigyeléses vizsgálatok, illetve regiszterek - nem mindig egybevágó - adatai szerint a szulfanilureák, elsősorban metforminkezeléssel összehasonlítva, növelhetik az SzE kialakulását, a hospitalizációt és a mortalitást, főleg nagyobb adagok esetén [22, 23, 51]. Második generációs szulfanilureák 18-30\%-kal növelték az SzE előfordulását a metforminhoz képest egy angliai családorvosi adatbázist alapul vevő vizsgálatban [52].

Összegezve: A második generációs szulfanilureák biztonságosak cardiovascularis szempontból. Második vonalbeli szerként, alacsony dózisban ajánlhatók az ischaemiás prekondicionálást nem gátló, illetve elhúzódó hypoglykaemiát nem okozó szerek, így a glimepirid és a gliclazid. SzE-ben adásuk körültekintést igényel, biztonságosságuk tisztázása még nem lezárt.

\section{Meglitidinek}

A meglitidinek vagy prandialis cukorszabályzók az inzulinszekréciót ugyancsak az ATP-dependens káliumcsatornák zárása révén serkentik. A DDP-4-gátlók megjelenésével mára már nagyrészt kiszorultak a gyakorlatból. Az étkezésre bekövetkező inzulinelválasztás első fázisát fokozzák, közvetlenül a postprandialis időszakban, az éhomi vércukrot nem befolyásolják. A kiváltott inzulinelválasztás gyors és rövid ideig tart. Fő képviselőik a benzoesavszármazék repaglinid és a d-fenilanalin-származék nateglinid $[28,30]$.

A meglitidinek ritkábban okoznak hypoglykaemiát és krónikus hyperinsulinaemiát, valamint kevésbé emelik a testsúlyt a szulfonilureákhoz viszonyítva, ami kedvező lehet cardiovascularis szempontból. Ugyancsak elönyt jelenthetnek a gyulladásos markerekre, egyes lipidparaméterekre, valamint a vérlemezke-funkcióra kifejtett hatásaik [30, 38].

Bár egy randomizált klinikai vizsgálat azt találta, hogy antidiabetikus szerekkel előzőleg nem kezelt betegekben a repaglinid pozitívan befolyásolt néhány cardiovascularis rizikótényezőt - homocisztein, lipoprotein(a), plazminogénaktivátor-inhibitor - [53], jelenleg nincsenek meggyőző klinikai evidenciák a meglitidinek cardiovascularis eseményekre és mortalitásra gyakorolt hatásait illetően. A fellelhető tanulmányok eredményei sokszor ellentmondásosak: a NAVIGATOR (Nateglinide And Valsartan in Impaired Glucose Tolerance Outcomes Research) vizsgálatban a nateglinid nem csökkentette a placebóhoz képest a cardiovascularis események előfordulását, valamint a diabetes megjelenését csökkent glükóztolerancia esetén [54]; egy nagy esetszámú dán epidemiológiai tanulmányban a repaglinid nem emelte szignifikánsan a cardiovascularis események számát a metforminhoz képest, myocardialis infarctuson átesett betegek esetén sem [55]; a DYDA (Left Ventricular Dysfunction in Type 2 Diabetes Mellitus) vizsgálatban, amelyet cardiovascularis betegségben még nem szenvedő diabeteses betegeken végeztek, a repaglinid a bal kamrai diszfunkció kialakulásának független rizikófaktorának bizonyult [56].

Összegezve: A meglitidinek kevésbé hatékony antidiabetikus szerek, a szulfonilureák alternatívái, amelyeknek cardiovascularis biztonságossága, SzE esetén történő alkalmazhatósága még további vizsgálatokat igényel.

\section{Inkretinalapú kezelés}

A glucagon-like peptid-1 (GLP-1) a bél L-sejtjeiben termelődő inkretin hormon, amely fokozza a glükózfüggő inzulintermelést (az inzulingén transzkripcióját), serkenti a béta-sejt-proliferációt, csökkenti a postprandialis glükagonszekréciót (a szomatosztatin stimulálásán keresztül), csökkenti a gyomorürülést, valamint centrális mechanizmus útján csökkenti az étvágyat. A dipeptidilpeptidáz-4 (DPP-4) enzim hatására a GLP-1 nagyon gyorsan elbomlik, felezési ideje 1-2 perc [57]. Jelenleg a GLP-1-aktivitás növelésére két terápiás megközelítés áll rendelkezésünkre: egyrészt a GLP-1-mimetikumok alkalmazása, amelyek ellenállnak a DPP-4-hatásnak, másrészt a DPP-4-gátlók használata.

\section{GLP-1-mimetikumok}

A GLP-1-receptoragonisták és GLP-1-analógok eddigi képviselői mind injektábilis készítmények. A Magyarországon forgalomban levő, GLP-1-hatást utánzó szerek az exenatid (a napi kétszer adandó, fóleg a postprandialis értékekre ható Byetta és a lassú felszívódású, hetente egyszer adandó, fooleg az éhomi értékeket csökkentő Bydureon), a napi egyszeri adagolású lixisenatid (Lyxumia), a szintén napi egyszeri adagolású liraglutid (Victosa), a heti egyszeri adagolású, tartós hatású dulaglutid (Trulicity), valamint ennek a hosszú hatású deglutek inzulinnal való kombinációja (Xultophy), egyszeri napi adagolásban.

Vércukorcsökkentő hatásuk mellett minden képviselőjük enyhén csökkenti a vérnyomást és szignifikánsan csökkenti a testsúlyt (átlagosan 3-6 kg). Ilyen értelemben az FDA 2015-ben törzskönyvezte az Egyesült Államokban nem cukorbetegeken a $3 \mathrm{mg}$-os liraglutidot mint testsúlycsökkentő gyógyszert [58].

In vitro, in vivo és humán tanulmányok a GLP-1-mimetikumok előnyös cardiovascularis hatásait észlelték, használatuk esetén javult a balkamra-funkció, csökkent a szívritmuszavarok gyakorisága, javult az endothelfunkció, csökkent az oxidatív stressz, az endothelin-1-termelés, valamint a szívizomsejtek apoptózisa $[57,59]$.

A csoport minden készítményével létezik a cardiovascularis biztonságosságot célba vevő noninferioritási tanulmány. Ezek közül mind ez idáig a lixisenatidra vo- 
natkozó ELIXA (Evaluation of Lixisenatide in Acute Coronary Syndrome), a semaglutidra vonatkozó SUSTAIN-6 (Semaglutide in Subjects with Type 2 Diabetes), valamint a liraglutidra vonatkozó LEADER ( $\mathrm{Li}$ raglutide Effect and Action in Diabetes: Evaluation of Cardiovascular Outcome Results) tanulmányok kerültek bemutatásra.

A LEADER tanulmányban a liraglutid az elsődleges, összevont végpont vonatkozásában előnyösebbnek bizonyult a placebóhoz képest (kockázati arány 0,87), a cardiovascularis és az összhalálozás 22\%-kal, illetve 15\%-kal alacsonyabbnak bizonyult. Az SzE miatti hospitalizáció ugyan kevesebb betegnél jelent meg a liraglutidcsoportban a placebóhoz képest, de ez nem volt statisztikailag szignifikáns, a kacsdiuretikumok használata azonban szignifikánsan kisebb volt a liraglutidcsoportban [60].

Az ELIXA vizsgálatban bebizonyosodott a lixisenatid noninferioritása a placebóhoz képest a cardiovascularis végpontokat illetően, beleértve az SzE megjelenését is, akut coronariaszindrómán átesett betegekben [61]. A 2016 őszén bemutatott SUSTAIN-6 a semaglutid heti egyszeri adása kapcsán ugyancsak a molekula noninferioritását bizonyította, sőt az elsődleges összevont végpont (cardiovascularis halál, nem fatális myocardialis infarctus és stroke) vonatkozásában egy enyhe előnyt is észleltek (kockázati arány 0,74), a cardiovascularis elhalálozás azonban nem volt kisebb [62]. Megjegyezzük, hogy a semaglutid jelenleg még nem került forgalmazásra.

Az eddigi adatok alapján a gyógyszercsalád cardiovascularis vonatkozásban biztonságosnak tünik, az SzE okozta hospitalizáció nem gyakoribb, a testsúlycsökkentő hatás pedig külön előny a rizikócsökkentés szempontjából.

\section{DPP-4-gátlók}

Az inkretineket bontó DPP-4 enzim gátlása a GLP-1 hormonhatás felerősödését eredményezi. Lévén, hogy a DPP-4-hatásnak számtalan egyéb szubsztrátuma is van, a gátlás a szívizom jelátviteli rendszerét, az apoptózist, a kollagénképzést, valamint a vese $\mathrm{Na}-\mathrm{H}$ pumpáját is érinti [63].

Jelenleg, világszerte, tíz molekula van törzskönyvezve. Ezek közül Magyarországon a sitagliptin, saxagliptin, linagliptin, vildagliptin és az alogliptin kaphatók, metforminnal kombinált formában is, illetve az alogliptin pioglitazonnal együtt is. A napi egyszeri vagy kétszeri adagban adott orális készítmények toleranciája jó, nagyon kis mértékben hajlamosítanak hypoglykaemiára, nem járnak súlynövekedéssel [28, 30, 63].

Eddig három nagy, DPP-4-gátlókra vonatkozó cardiovascularis biztonságossági tanulmány eredményeit ismerjük.

A SAVOR-TIMI 53 (Saxagliptin Assessment of Vascular Outcomes Recorded in Patients with Diabetes Mellitus) tanulmány a saxagliptint vizsgálta 2 -es típusú cukorbetegeken. Az elsődleges, összevont végpont vo- natkozásában egyértelmű noninferioritás igazolódott, ugyanakkor az SzE okozta kórházi befekvés esélye 27\%kal magasabb volt a saxagliptint kapó csoportban amellett, hogy a perifériás oedema gyakorisága, a súlygyarapodás és az NT-proBNP növekedés nem volt nagyobb a placebocsoporthoz képest. Megjegyezzük, hogy az SzE miatti hospitalizáció kapcsán nem volt egyértelmúsítve, milyen okok vezettek a beutalásokhoz, azok gyakorisága országonként és régiónként nagyban változott. Ugyanakkor a hospitalizáció az első évben jelentkezett, és rendszerint azoknál, akiknél kiinduláskor már jelen voltak az SzE tünetei. Ezért az utólagos elemzések óvatosan fogalmaznak az SzE-re vonatkozó következtetések vonatkozásában [64].

Az alogliptinnel végzett EXAMINE (Examination of Cardiovascular Outcomes with Alogliptin versus Standard of Care) tanulmány nem észlelte az SzE gyakoriságának növekedését, a cardiovascularis morbiditás és mortalitás vonatkozásában pedig noninferioritás igazolódott [65].

A TECOS (Trial to Evaluate Cardiovascular Outcomes after Treatment with Sitagliptin) tanulmányban a sitagliptin nem növelte a cardiovascularis morbiditást és mortalitást. A gyógyszer a súlyos SzE kialakulásának esélyét nem emelte (kockázati arány 1,00) [66].

A három prospektív tanulmány bizonyítja, hogy általánosságban véve a gyógyszercsalád nem növeli a cardiovascularis mortalitási, morbiditási kockázatot. Saxagliptin esetén az SzE-et érintő negatív hatás valószínúleg a betegpopuláció nem megfelelő randomizálása miatt léphetett fel [67].

\section{SGLT-2-gátlók}

A szelektív, nátriumdependens glükózkotranszporter-2 (sodium-glucose cotransporter-2, SGLT-2) -gátlók (gliflozinok) képezik a legújabb orális antidiabetikus gyógyszercsaládot. 2013-ban került piacra első képviselőjük, a canagliflozin, majd ezt követte a dapagliflozin, illetve az empagliflozin törzskönyvezése úgy az Egyesült Államokban, mint az Európai Unióban. Magyarországon ez utóbbi kettő kapható, metforminnal kombinált formában is.

A gyógyszercsalád célszerve a vese, amely részt vesz a glükózhomeosztázis kialakításában a glükoneogenezis, valamint a glükóz filtrációja és reabszorpciója által. Ez utóbbi aktív transzport segítségével történik, a szelektív, nátriumhoz kapcsolt glükózkotranszporterek (SGLT) által. A vesében a transzporterek 90\%-a SGLT-2 típusú, amely nagy kapacitású, kis affinitású molekula, és a proximális tubulusok SI szegmentumában található. Az SGLT-2-gátlók a glükóz reabszorpcióját akadályozzák meg, ezáltal akár 70-80 g/nap mennyiségú glucosuria is létrejöhet (ez 280-320 kcal/nap veszteség), a vércukorszint következményes csökkenésével. A nátrium visszaszívódását is csökkentik, ezáltal enyhén diuretikus hatásúak. Hatásukra csökken az inzulinszint, emelkedik a 
glükagonszint, illetve enyhe hyperketonaemia alakul ki. A ketontestek előnyösebb metabolikus szubsztrátumai az inzulinrezisztens szívizomnak, mint a szabad zsírsavak $[28,30,68,69]$.

A gliflozinok csökkentik a vérnyomást (4-10 Hgmmrel), a testsúlyt (-2 kg), a húgysavszintet, az érfalmerevséget és az albuminuriát. Mellékhatásként a nemi szervek gombás fertőzése, vizeletfertőzés, illetve nagyon ritkán enyhe ketoacidosis alakulhat ki $[68,69]$.

A csoport gyógyszereivel több noninferioritási tanulmányt is terveztek: ilyen a CANVAS (Canagliflozin Cardiovascular Assessment Study), amely 2017-ben zárul, a DECLARE-TIMI 58 (Dapagliflozin Effect on Cardiovascular Events), amely 2019-ben zárul, valamint az EMPA-REG OUTCOME (Empagliflozin Cardiovascular Outcome Event Trial in Type 2 Diabetes Mellitus Patients), amelynek eredményeit 2015 őszén tették közzé. Ez utóbbi vizsgálatba magas cardiovascularis rizikójú 2-es típusú cukorbetegeket randomizáltak, és az elsődleges összevont végpont (cardiovascularis halál, nem fatális myocardialis infarctus és stroke) terén igazolható volt az empagliflozin fölénye (kockázati arány 0,86 ). A cardiovascularis eredetû halál kockázata 38\%-kal csökkent az empagliflozinágon, ami nagyságrendben a béta-blokkolók SzE-ben észlelt mortalitást csökkentő hatásának felel meg. 32\%-os kockázatcsökkenést tapasztaltak az összhalálozás alakulása terén is, míg az SzE miatti hospitalizáció 35\%-kal volt kevesebb. Ilyen mérvü cardiovascularis kockázatcsökkenés eddig egyetlen diabetológiai tanulmányban sem volt kimutatható. A pozitív hatások vélhetően a volumendepléciónak, illetve a már említett ketonaemiának tudhatók be, és tulajdonképpen az SzE klinikai javulásának voltak köszönhetők [70].

Az SGLT-2-gátlók különböző molekuláit felölelő tanulmányokat magukba foglaló metaanalízisek szintén a cardiovascularis, illetve összhalálozás, valamint az SzE miatti hospitalizáció csökkenését állapították meg. Az egyes molekulák között nem volt különbség [71, 72].

Az eddigi adatok alapján nem kizárt, hogy az SGLT2-gátlók az SzE gyógyszerarzenáljának egy újabb tagját képezik majd, akár cukorbetegség hiányában is. Az ilyen irányú prospektív tanulmányok folyamatban vannak.

\section{Következtetések}

SzE és diabetes társulása gyakori, a két kórállapot egymásra hatása növeli a cardiovascularis események előfordulását, illetve a mortalitást. A gyakorlatban előnyt élvez azoknak az antidiabetikus szereknek az alkalmazása, amelyeknek cardiovascularis hatásai kedvezőek, illetve az SzE-et nem befolyásolják negatívan. Az adatok ilyen értelemben egyértelmüen alátámasztják a metformin és a gliflozinok (SGLT-2-gátlók) kedvező és a thiazolidindionok káros hatását. A többi gyógyszercsoport alkalmazása SzE esetén megengedett, de fontos a dekompenzáció jeleinek folyamatos monitorozása.
Anyagi támogatás: A közlemény megírása anyagi támogatásban nem részesült.

Szerzôi munkamegosztás: F. A.: A kézirat megszövegezése, a bevezetés, az inzulin, a biguanidok alfejezet és öszszefoglalás megírása, a táblázat összeállítása, az irodalom rendszerezése, a dolgozat végső szerkesztése. G.-S. M.: A kézirat megszövegezése, a szulfanilureák, a meglitidinek alfejezet megírása. M. L.: A kézirat megszövegezése, a thiazolidindionok és az alfa-glükozidáz-gátlók alfejezet összeállítása. Sz. M.: A kézirat megszövegezése, az inkretinalapú kezelés, az SGLT-2-gátlók alfejezet megírása, az alfejezetek belső lektorálása. A cikk végleges változatát valamennyi szerző elolvasta és jóváhagyta.

Érdekeltségek: A szerzőknek a cikk megírását illetően nincsenek érdekeltségeik.

\section{Irodalom}

[1] Tamayo, T., Rosenbauer, J., Wild, S. H., et al.: Diabetes in Europe: an update. Diabetes Res. Clin. Pract., 2014, 103(2), 206217.

[2] Kannel, W. B., Hjortland, M., Castelli, W. P.: Role of diabetes in congestive heart failure: the Framingham study. Am. J. Cardiol., 1974, 34(1), 29-34.

[3] Dei Cas, A., Khan, S. S., Butler, J., et al.: Impact of diabetes on epidemiology, treatment, and outcomes of patients with heart failure. JACC Heart Fail., 2015, 3(2), 136-145.

[4] Cubbon, R. M., Adams, B., Rajwani, A., et al.: Diabetes mellitus is associated with adverse prognosis in chronic heart failure of ischaemic and non-ischaemic aetiology. Diab. Vasc. Dis. Res., 2013, 10(4), 330-336.

[5] Dei Cas, A., Fonarow, G. C., Gheorghiade, M., et al.: Concomitant diabetes mellitus and heart failure. Curr. Probl. Cardiol., 2015, 40(1), 7-43.

[6] Rydén, L., Grant, P. J., Anker, S. D., et al.: ESC Guidelines on diabetes, pre-diabetes, and cardiovascular diseases developed in collaboration with the EASD. Eur. Heart J., 2013, 34(39), 3035-3087.

[7] Low Wang, C. C., Reusch, J. E.: Diabetes and cardiovascular disease: Changing the focus from glycemic control to improving long-term survival. Am. J. Cardiol., 2012, 110 (9 Suppl.), 58B$68 \mathrm{~B}$.

[8] Kumar, R., Kerins, D. M., Walther, T.: Cardiovascular safety of anti-diabetic drugs. Eur. Heart J. Cardiovasc. Pharmacother., 2016, 2(1), 32-43.

[9] Azimova, K., San Juan, Z., Mukherjee, D.: Cardiovascular safety profile of currently available diabetic drugs. Ochsner J., 2014, 14(4), 616-632.

[10] Inzucchi, S. E., Bergenstal, R. M., Buse, J. B., et al.: Management of hyperglycaemia in type 2 diabetes, 2015: a patient-centred approach. Update to a Position Statement of the American Diabetes Association and the European Association for the Study of Diabetes. Diabetologia, 2015, 58(3), 429-442.

[11] Turnbull, F. M., Abraira, C., Anderson, R. J., et al: Intensive glucose control and macrovascular outcomes in type 2 diabetes. Diabetologia, 2009, 52(11), 2288-2298.

[12] Muniyappa, R., Montagnani, M., Kon, K. K., et al.: Cardiovascular actions of insulin. Endocr. Rev., 2007, 28(5), 463-491.

[13] Fitchett, D. H., Udell, J. A., Inzucchi, S. E.: Heart failure outcomes in clinical trials of glucose-lowering agents in patients with diabetes. Eur. J. Heart Fail., 2017, 19(1), 43-53. [Epub 2016 Sep 21] 
[14] UK Prospective Diabetes Study (UKPDS) Group: Intensive bloodglucose control with sulphonylureas or insulin compared with conventional treatment and risk of complications in patients with type 2 diabetes (UKPDS 33). Lancet, 1998, 352(9131), 837853.

[15] Gerstein, H. C., Bosch, J., Dagenais, G. R., et al., ORIGIN Trial Investigators: Basal insulin and cardiovascular and other outcomes in dysglycemia. N. Engl. J. Med., 2012, 367(4), 319-328.

[16] Smooke, S., Horwich, T. B., Fonarow, G. C.: Insulin-treated diabetes is associated with a marked increase in mortality in patients with advanced heart failure. Am. Heart J., 2005, 149 (1), 168174.

[17] Winkler, G.: Metformin - new data of an "old", but efficient, safe and reliable antidiabetics. [Metformin - újabb adatok egy megbízható és hatékony „régi” vércukorcsökkentő készítményrőll.] Orv. Hetil., 2016, 157(23), 882-891. [Hungarian]

[18] El Messaoudi, S., Rongen, G. A., de Boer, R. A., et al.: The cardioprotective effects of metformin. Curr. Opin. Lipidol., 2011, $22(6), 445-453$.

[19] UK Prospective Diabetes Study (UKPDS) Group: Effect of intensive blood-glucose control with metformin on complications in overweight patients with type 2 diabetes (UKPDS 34). Lancet, 1998, 352(9131), 854-865.

[20] Lamanna, C., Monami, M., Marchionni, N., et al.: Effect of metformin on cardiovascular events and mortality: a meta-analysis of randomized clinical trials. Diabetes Obes. Metab., 2011, 13(3), 221-228.

[21] Eurich, D. T., Weir, D. L., Majumdar, S. R., et al.: Comparative safety and effectiveness of metformin in patients with diabetes mellitus and heart failure: systematic review of observational studies involving 34,000 patients. Circ. Heart Fail., 2013, 6(3), 395-402.

[22] Eurich, D. T., Majumdar, S. R., McAlister, F. A., et al.: Improved clinical outcomes associated with metformin in patients with diabetes and heart failure. Diabetes Care, 2005, 28(10), 23452351.

[23] Masoudi, F. A., Inzucchi, S. E., Wang, Y., et al.: Thiazolidinediones, metformin, and outcomes in older patients with diabetes and heart failure: an observational study. Circulation, 2005, $111(5), 583-590$

[24] Shah, D. D., Fonarow, G. C., Horwich, T. B.: Metformin therapy and outcomes in patients with advanced systolic heart failure and diabetes. J. Card. Fail., 2010, 16(3), 200-206.

[25] McAlister, F. A., Eurich D. T., Majumdar, S. R., et al.: The risk of heart failure in patients with type 2 diabetes treated with oral agent monotherapy. Eur. J. Heart Fail., 2008, 10(7), 703-708.

[26] Dreyer, C., Krey, G., Keller, H., et al.: Control of the peroxisomal beta-oxidation pathway by a novel family of nuclear hormone receptors. Cell, 1992, 68(5), 879-887.

[27] Nissen, S. E., Wolski, K.: Rosiglitazone revisited: an updated meta-analysis of risk for myocardial infarction and cardiovascular mortality. Arch. Intern. Med., 2010, 170(14), 1191-1201.

[28] Timár, J.: Pancreatic hormones and the drugs for diabetes mellitus. In: Gyires, K., Fürst, Zs., Ferdinandy, P. (eds): Pharmacology and clinical pharmacology. [A pancreashormonok és a diabetes mellitus gyógyszerei. In: Gyires, K., Fürst, Zs., Ferdinandy, P. (szerk.): Farmakológia és klinikai farmakológia.] Medicina Könyvkiadó, Budapest, 2016, 294-313. [Hungarian]

[29] Duan, S.Z., Usher, M. G., Mortensen, R. M.: PPARs: the vasculature, inflammation and hypertension. Curr. Opin. Nephrol. Hypertens., 2009, 18(2), 128-133.

[30] Jermendy, Gy. (ed.): Diagnosis of diabetes, treatment and management of adult diabetic patients: Guidelines of the Hungarian Association of Diabetes, 2014. [A diabetes mellitus kórismézése, a cukorbetegek kezelése és gondozása felnőttkorban: A Magyar Diabetes Társaság szakmai irányelve, 2014.] Diabetol. Hung., 2014, 22 (Suppl. 1), 2-84. [Hungarian]
[31] Goltsman, I., Khoury, E. E., Winaver, J., et al.: Does thiazolidin edione therapy exacerbate fluid retention in congestive heart failure? Pharmacol. Ther., 2016, 168, 75-97.

[32] Erdmann, E., Charbonnel, B., Wilcox, R. G., et al., PROactive Investigators: Pioglitazone use and heart failure in patients with type 2 diabetes and preexisting cardiovascular disease: data from the PROactive study (PROactive 08). Diabetes Care, 2007, 30(11), 2773-2778.

[33] Lincoff, A. M., Wolski, K., Nicholls, S. J., et al.: Pioglitazone and risk of cardiovascular events in patients with type 2 diabetes mellitus: a meta-analysis of randomized trials. JAMA, 2007, 298(10), $1180-1188$.

[34] Graham, D. J., Ouellet-Hellstrom, R., MaCurdy, T. E., et al.: Risk of acute myocardial infarction, stroke, heart failure, and death in elderly Medicare patients treated with rosiglitazone or pioglitazone. JAMA, 2010, 304(4), 411-418.

[35] Home, P. D., Pocock, S. J., Beck-Nielsen, H., et al., for the RECORD Study Team: Rosiglitazone evaluated for cardiovascular outcomes in oral agent combination therapy for type 2 diabetes (RECORD): a multicentre, randomised, open-label trial. Lancet, 2009, 373(9681), 2125-2135.

[36] Singh, S., Loke, Y. K., Furberg, C. D.: Long-term risk of cardiovascular events with rosiglitazone: a meta-analysis. JAMA, 2007, 298(10), 1189-1195.

[37] Lago, R. M., Singh, P. P., Nesto R. W.: Congestive heart failure and cardiovascular death in patients with prediabetes and type 2 diabetes given thiazolidinediones: a meta-analysis of randomised clinical trials. Lancet, 2007, 370(9593), 1129-1136.

[38] Joshi, P. H., Kalyani, R. R., Blumenthal, R. S., et al.: Cardiovascular effects of noninsulin, glucose-lowering agents: need for more outcomes data. Am. J. Cardiol., 2012, 110 (9 Suppl.), $32 \mathrm{~B}-42 \mathrm{~B}$.

[39] Chiasson, J. L., Josse, R. G., Gomis, R., et al., for The STOPNIDDM Trial Research Group: Acarbose treatment and the risk of cardiovascular disease and hypertension in patients with impaired glucose tolerance: the STOP-NIDDM trial. JAMA, 2003, 290(4), 486-494.

[40] Hanefeld, M., Cagatay, M., Petrowitsch, T., et al.: Acarbose reduces the risk for myocardial infarction in type 2 diabetic patients: meta-analysis of seven long-term studies. Eur. Heart J., 2004, 25(1), 10-16.

[41] Van de Laar, F. A., Lucassen, P. L.: No evidence for a reduction of myocardial infarctions by acarbose. Eur. Heart J., 2004, 25 (13), $1179-1180$.

[42] Winkler, G.: Sulfonylureas in today's blood glucose lowering therapy. New data on advantages and potential barriers of an "old" antidiabetic group. [Szulfanilureák napjaink vércukorcsökkentő kezelésében. Újabb adatok egy régi gyógyszercsoport előnyeiről és korlátairól.] Orv. Hetil., 2015, 156(13), 511-515. [Hungarian]

[43] Heller, S. R., ADVANCE Collaborative Group: A Summary of the ADVANCE Trial. Diabetes Care, 2009, 32(Suppl. 2), S357S361.

[44] Rydén, L., Shahim, B., Mellbin, L.: Clinical implications of cardiovascular outcome trials in type 2 diabetes: from DCCT to EMPA-REG. Clin. Ther., 2016, 38(6), 1279-1287.

[45] Hemmingsen, B., Schroll, J. B., Wetterslev, J.: Sulfonylurea versus metformin monotherapy in patients with type 2 diabetes: a Cochrane systematic review and meta-analysis of randomized clinical trials and trial sequential analysis. CMAJ Open, 2014, 2(3), E162-E175.

[46] Zoungas, S., Patel, A., Chalmers, J., et al., for the ADVANCE Collaborative Group: Severe hypoglycemia and risks of vascular events and death. N. Engl. J. Med., 2010, 363(15), 1410-1418.

[47] Rados, D. V., Pinto, L. C., Remonti, L. R., et al.: The association between sulfonylurea use and all-cause and cardiovascular mortality: a meta-analysis with trial sequential analysis of randomized clinical trials. PLoS Med., 2016, 13(4), el001992. 
[48] Schramm, T. K., Gislason, G. H., Vaag, A., et al.: Mortality and cardiovascular risk associated with different insulin secretagogues compared with metformin in type 2 diabetes, with or without a previous myocardial infarction: a nationwide study. Eur. Heart J., 2011, 32(15), 1900-1908.

[49] Simpson, S. H., Lee, J., Choi, S., et al.: Mortality risk among sulfonylureas: a systematic review and network meta-analysis. Lancet Diabetes Endocrinol., 2015, 3(1), 43-51.

[50] Giles, T. D., Elkayam, U., Bhattacharya, M., et al.: Comparison of pioglitazone vs glyburide in early heart failure: insights from a randomized controlled study of patients with type 2 diabetes and mild cardiac disease. Congest. Heart Fail., 2010, 16(3), 111117.

[51] Pantalone, K. M., Kattan, M. W., Үu, C., et al.: The risk of developing coronary artery disease or congestive heart failure, and overall mortality, in type 2 diabetic patients receiving rosiglitazone, pioglitazone, metformin, or sulfonylureas: a retrospective analysis. Acta Diabetol., 2009, 46(2), 145-154.

[52] Tzoulaki, I., Molokbia, M., Curcin, V., et al.: Risk of cardiovascular disease and all cause mortality among patients with type 2 diabetes prescribed oral antidiabetes drugs: retrospective cohort study using UK general practice research database. BMJ, 2009, $339, \mathrm{~b} 4731$

[53] Derosa, G., Mugellini, A., Ciccarelli, L., et al.: Comparison between repaglinide and glimepiride in patients with type 2 diabetes mellitus: A one-year, randomized, double-blind assessment of metabolic parameters and cardiovascular risk factors. Clin. Ther., $2003,25(2), 472-484$.

[54] Holman, R. R., Haffner, S. M., McMurray, J. J., et al., The NAVIGATOR Study Group: Effect of nateglinide on the incidence of diabetes and cardiovascular events. N. Engl. J. Med., 2010, 362(16), 1463-1476.

[55] Schramm, T. K., Gislason, G. H., Vaag, A., et al.: Mortality and cardiovascular risk associated with different insulin secretagogues compared with metformin in type 2 diabetes, with or without a previous myocardial infarction: a nationwide study. Eur. Heart J., 2011, 32(15), 1900-1908.

[56] Cioffi, G., Faggiano, P., Lucci, D., et al.: Left ventricular dysfunction and outcome at two-year follow-up in patients with type 2 diabetes: The DYDA study. Diabetes Res. Clin. Pract., 2013, 101(2), 236-242.

[57] Lindamood, C. A., Taylor, J. R.: Emerging new therapies for the treatment of type 2 diabetes mellitus: glucagon-like peptide-1 receptor agonists. Clin. Ther., 2015, 37(3), 483-493.

[58] Pi-Sunyer, X., Astrup, A., Fujioka, K., et al.: A randomized, controlled trial of $3.0 \mathrm{mg}$ of liraglutide in weight management. $\mathrm{N}$. Engl. J. Med., 2015, 373(1), 11-22.

[59] Jeremendy, Gy.: Cardiovascular safety of incretin-based antidiabetic treatment - results of completed clinical trials. [Az inkretintengelyen ható antidiabetikumokkal végzett cardiovascularis biztonságossági tanulmányok eddigi tapasztalatai.] Orv. Hetil., 2016, 157(16), 603-610. [Hungarian]

[60] Marso, S. P., Daniels, G. H., Brown-Frandsen, K., et al., for the LEADER Steering Committee on behalf of the LEADER Trial Investigators: Liraglutide and cardiovascular outcomes in type 2 diabetes. N. Engl. J. Med., 2016, 375(4), 311-322.

[61] Pfeffer, M. A., Claggett, B., Diaz, R., et al., for the ELIXA Investigators: Lixisenatide in patients with type 2 diabetes and acute coronary syndrome. N. Engl. J. Med., 2015, 373(23), $2247-$ 2257.
[62] Marso, S. P., Bain, S., Consoli, A., et al., for the SUSTAIN-6 Investigators: Semaglutide and cardiovascular outcomes in patients with type 2 diabetes. N. Engl. J. Med., 2016, 375(19), 18341844.

[63] Chen, X. W., He, Z. X., Zhou, Z. W., et al.: Clinical pharmacology of dipeptidyl peptidase 4 inhibitors indicated for the treatment of type 2 diabetes mellitus. Clin. Exp. Pharmacol. Physiol., 2015, 42(10), 999-1024.

[64] Scirica, B. M., Bhatt, D. L., Braunwald, E., et al., for the SAVOR-TIMI 53 Steering Committee and Investigators: Saxagliptin and cardiovascular outcomes in patients with type 2 diabetes mellitus. N. Engl. J. Med., 2013, 369(14), 1317-1326.

[65] White, W. B., Cannon, C. P., Heller, S. R., et al., for the EXAMINE Investigators: Alogliptin after acute coronary syndrome in patients with type 2 diabetes. N. Engl. J. Med., 2013, 369(14), 1327-1335.

[66] McGuire, D. K., Van der Werf, F., Armstrong, P. W., et al., for the Trial Evaluating Cardiovascular Outcomes With Sitagliptin (TECOS) Study Group: Association between sitagliptin use and heart failure hospitalization and related outcomes in type 2 diabetes mellitus. Secondary analysis of a randomized clinical trial. JAMA Cardiol., 2016, 1(2), 126-135.

[67] Jermendy, Gy.: Cardiovascular safety of DPP-4-inhibitors - results of clinical trials completed so far. [A DPP-4-gátlók cardiovascularis biztonságossága - a napjainkig lezárult nagy klinikai tanulmányok eredményei.] Cardiologia Hungarica, 2015, 45(3), 199-205. [Hungarian]

[68] Tahara, A., Takasu, T., Yokono, M., et al.: Characterization and comparison of sodium-glucose cotransporter 2 inhibitors in pharmacokinetics, pharmacodynamics, and pharmacologic effects. J. Pharmacol. Sci., 2016, 130(3), 159-169.

[69] Simonyi, G.: New possibility in the oral glucose lowering treatment of type 2 diabetes mellitus: sodium-glucose co-transporter-2 inhibitors. [Új lehetőség a 2-es típusú diabetes mellitus oralis vércukorcsökkentő terápiájában: a nátrium-glükóz kotranszporter-2-gátlók.] Orv. Hetil., 2012, 153(18), 695-701. [Hungarian]

[70] Zinman, B., Wanner, C., Lachin, J. M., et al., for the EMPA-REG OUTCOME Investigators: Empagliflozin, cardiovascular outcomes, and mortality in type 2 diabetes. N. Engl. J. Med., 2015, $373(22), 2117-2128$.

[71] Wu J. H., Foote, C., Blomster, J., et al.: Effects of sodium-glucose cotransporter- 2 inhibitors on cardiovascular events, death, and major safety outcomes in adults with type 2 diabetes: a systematic review and meta-analysis. Lancet Diabetes Endocrinol., 2016, 4(5), 411-419.

[72] Monami, M., Dicembrini, I., Mannucci, E.: Effects of SGLT-2 inhibitors on mortality and cardiovascular events: a comprehensive meta-analysis of randomized controlled trials. Acta Diabetol., 2016 Aug 4. doi: 10.1007/s00592-016-0892-7 [Epub ahead of print]. Erratum in: Acta Diabetol., 2016 October 11. doi:10.1007/s00592-016-0922-5

(Frigy Attila dr.,

UMF Tg. Mureș, Internal Medicine IV Gh., Marinescu str. 1., 540400 Târgu Mureş, Romania e-mail: afrigy68@gmail.com) 